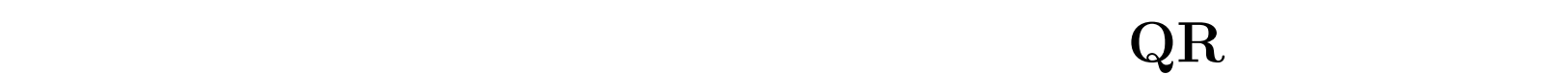

\author{
小野智司 ${ }^{\dagger}$ 森永 健介 ${ }^{\dagger}$ 中山茂 ${ }^{\dagger}$ \\ $\dagger$ 鹿児島大学 工学部 情報工学科
}

\begin{abstract}
要旨

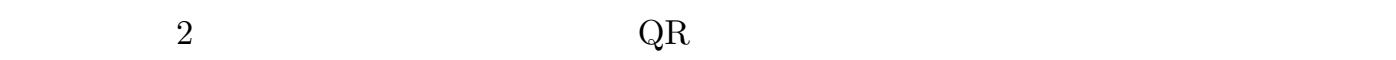
ることを目的として，QR コードにイラストや写真を上書きする方式を提案する ·提案する方 式は，イラストの配置決定を最適化問題として定式化し，汎用の最適化アルゴリズムを用いる

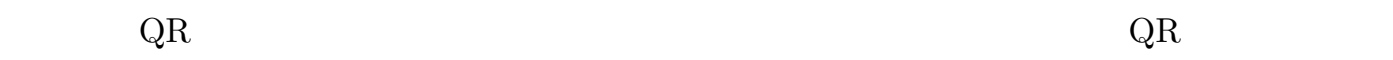
置することができる . 本論文で提案する方式を用いて, 実際にイラスト入り静止画および動画 QR コードを生成できることを示す．

$$
\text { キーワード }
$$

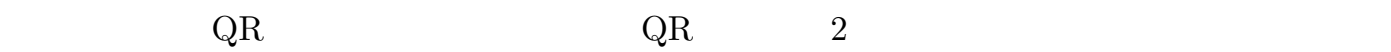
ルゴリズム
\end{abstract}

\section{Animated QR Code Generation Using Optimization Algorithms}

\author{
Satoshi Ono ${ }^{\dagger}$ Kensuke Morinaga ${ }^{\dagger} \quad$ Shigeru Nakayama ${ }^{\dagger}$ \\ $\dagger$ Department of Information and Computer Science, \\ Faculty of Engineering, Kagoshima University
}

\begin{abstract}
This paper proposes a method for decorating QR code, a kind of 2-dimensional barcode, with some illustrations inside the code in order to enhance the attractiveness and lookand-feel of the QR code. The proposed system formulates the task of finding appropriate positions, scales, and angles of illustrations, and solves the task by using general-purpose optimization solvers. The proposed system can therefore merge illustrations into the code without detracting machine-readability and stored information. This paper has shown that the proposed method could decorate still and animated barcode images with illustrations inside the code.
\end{abstract}

\section{Keywords}

QR code with illustrations, 2-dimensional barcode, animated QR code, optimization, genetic algorithm 


\section{1 はじめに}

バーコードは物流用途を中心に，樣々な目的で利用さ れている. 従来は 1 次元のバーコードが主に用いられ ていたが，近年，より情報量が多い 2 次元バーコード が広く用いられている . 2 次元バーコードの一種である QR (Quick Response) コード*は，印刷媒体などから 電子メールや Web ページのアドレスを手軽に取得でき る，いわゆる「ショートカット」として近年の日本で広 く利用されている.日本で販売されている多くの携帯

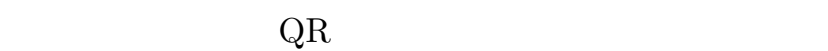
紙，看板に印刷された QR コードや，テレビに表示され た QR コードを，携帯電話で走査することで，QR コー ドに埋め込まれた情報を容易に取得できる．

$\mathrm{QR}$ コードは URL, 電子メールアドレス等のテキス 卜や短い演奏データを埋め込むことができるものの，ど

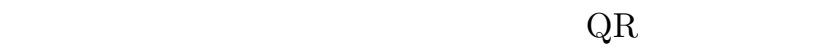
から走査前に知ることはできない．また，QR コードの 存在は，紙や看板の限られた貴重な領域を消費してしま う.さらに，QR コードの普及が進むにつれて珍しさが 薄れており，QR コードを利用するだけでは注目を集め るのが難しくなっている．より多くの人の関心を集め， $\mathrm{QR}$ コードを介して情報を提供するためには，QR コー ドの視覚的誘引性を高めることが必要となる．

$\mathrm{QR}$ コードはエラー訂正符号を備えており，最大で $30 \%$ のデータ欠損を復元することができる . このエラー

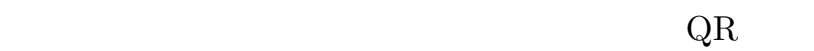
ドの領域内に配置することができる．イラストが上書き

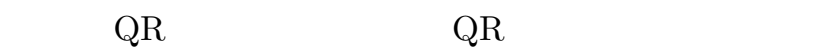
誘引性が高いことに加え，QR コードに埋め込まれた情 報の種類を示すことも可能となる .

しかし，QR コード上にイラストを描画することは， 携帯電話等のデコーダによる可読性を損ねる可能性が ある．エラ一訂正符号が適切に働き，埋め込まれた情 報を破壊しないようにイラストを描画する位置やサイ ズを決定する作業は試行錯誤的に行わなければならず， 大きなイラストや多数のイラストを描画することは困 難である .

本論文では, 埋め込まれた情報を損ねないように QR コード上にイラストを配置する方式を提案する . 提案す る方式では, イラスト, ロゴ等のイメージを QR コード 上に配置する問題を最適化問題として定式化し , 汎用の 解探索ソルバを用いて解を求めることで，埋め込まれた 情報を損ねないようにイラストが配置された QR コー ドを生成することができる．

本論文では，遺伝的アルゴリズム (Genetic Algorithm: GA) を用いてイラスト入り QR コードの生成 を行った.また，山登り法 (Hill Climbing: HC) を用

*QR コードは (株) デンソーウェーブの登録商標である .

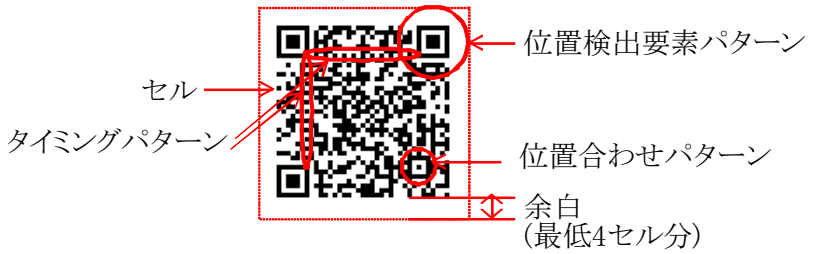

図 1: QR コード

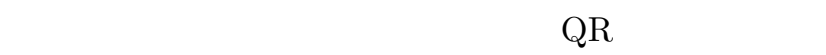
した . 作成したイラスト入り QR コードが，実際の携 帯電話でデコードが可能であることを確認した . また， 複数のイラストを配置した QR コードを生成できるこ とを確認した .

以下, 2 章では $\mathrm{QR}$ コードの概要について述べ, 3 章 では提案するイラスト入り QR コード生成方式について 説明する .4 章では， 3 章で述べた方式のアニメーショ ン $\mathrm{QR}$ コードへの拡張について述べる . 5 章では, 実際

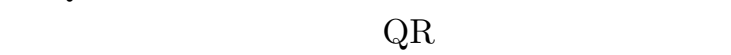

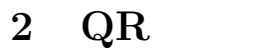

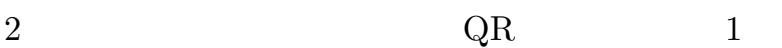
示すように，位置検出パターンを四隅のうち 3 箇所に 持ち，枡目状のデータパターンを含む．個々のデータ パターンを表す最小の矩形をセルと呼び，QR コードの 周囲には 4 セル分の余白が必要である. QR コードは数 值，アルファベット，日本語など樣々な情報を格納する ことができ, 数字であれば最大 7,089 桁, 英数字であれ ば最大 4,296 文字，漢字であれば最大 1,817 文字のデー タを埋め込むことができる .

QR コードは，携帯電話の利用者が容易に個人や情報 にアクセスできる手段を提供でき，Webページの URL やメールアドレスが埋め込まれた QR コードは, 広告 やパンフレット, 看板, 名刺など, 樣々な媒体で広く用

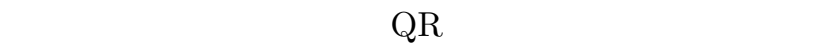
携帯電話を用いて印刷された QR コードを撮影するこ とで, URLやメールアドレスの入力の手間を省くこと ができ，アナログ媒体からネットワーク上の媒体への ショートカットとしての利便性が高い [1] . QR コード を作成することは容易であり，一般のユーザであっても 無償配布されている樣々なソフトウェアやWeb サービ スを利用することで，独自の情報を埋め込んだ QR コー ドを容易に作成することができる．

QR コードはリードソロモン符号 $[2]$ を用いることで， データの誤りを検出，訂正することができる．ハミング 符号などと比較して，連続して発生する誤りを訂正で きるなど，より高い誤り訂正能力を持つ．QR コードの 


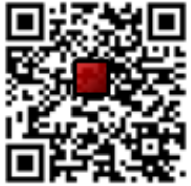

(a) Level L.

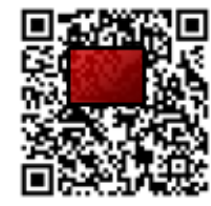

(c) Level Q.

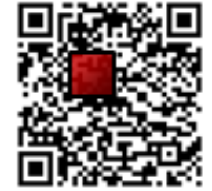

(b) Level M.

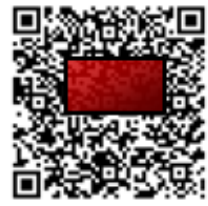

(d) Level H.
図 2: 誤り訂正レベル

誤り訂正能力はレベル $\mathrm{L}, \mathrm{M}, \mathrm{Q}$ ，および $\mathrm{H}$ の 4 段階を 設定することができ，乥れ光れ $7 \% ， 15 \% ， 25 \%$ ，およ び $30 \%$ の損傷データを復元することができる . 一辺 21 セルのバージョン 1 から一辺 177 セルのバージョン 40 までの QR コードが設定されており，埋め込むデータ 量か増加すると高いバージョンの QR コードを用いる 必要がある．また，図 2 に示すように, 同じ量のデータ を埋め込む場合でも，誤り訂正レベルに応じてバージョ ンが高くなる

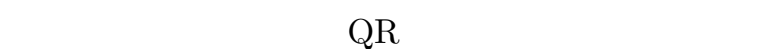
方法は，デザイナによって手動または半自動で行われ ている. IT DeSign 社が提供しているイラスト入り QR コードの生成サービス は, 埋め込むイラストと最も類 似する部分画像領域を QR コードから検索し，発見し た部分画像領域を埋め込むイラストと最も類似するよ うに書き換える方法を用いている $[3]$.

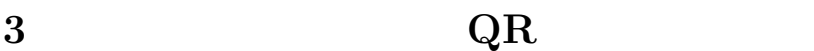

\section{1 方針および特徵}

提案するイラスト入り QR コード生成方式の方針を 以下に示す .

1) イラストの配置位置決定を最適化問題として定式 化する.

QR コードに埋め込まれたデータを損ねないようイ ラストを $\mathrm{QR}$ コード上に上書きするためには，試 行錯誤的にイラストの配置位置を決定する必要が ある.このため，イラストの配置位置などを設計変 数とし，デコード可能性とイラスト配置の品質を 目的関数とする最適化問題として定式化する.これ
により，山登り法 $[4,5]$ や焼き鈍し法 $[6]$ ，遺伝的ア ルゴリズム (Genetic Algorithm: GA) [7, 8, 9, 10] などの汎用の最適化ソルバを用いて解を求めるこ とにより, 最適なイラスト挿入位置を求めること ができる .

3.2 節および 3.5 節で後述する定式化法および解候 補の評価方法は最適化アルゴリズムに依存しない ため，本方式では樣々な最適化アルゴリズムの利 用が可能であるが，本論文では以下の理由により GA を用いて静止画 QR コードの装飾を行う.

- 大域的な探索に適しており，多樣な解の発見 が期待できる .

・複数の解候補を出力できる .

・最低限の局所解脱出能力を備える .

- 目的関数の妥当性の評価, 解析を行いやすい よう，アルゴリズムの挙動か既知であること か望ましい。

2) 複数のソフトゥェアデコーダを用いて, 解候補の 評価を行う。

市販されている携帯電話が搭載している QR コー ドデコーダは公開されておらず，本方式で同じ $\mathrm{QR}$ コードデコーダを用いることは困難である．この ため, 本方式では, 複数のソフトウェア QR コー ドデコーダを併用することで，生成したイラスト 入り $\mathrm{QR}$ コードのデコード可能性を検証する .よ り多くのソフトウェアデコーダを用いることで，よ りデコード可能性の高いイラスト入り QR コード を生成することができる .

なお，提案する方式では，イラスト以外にも写真，文 字などの樣々な画像を挿入することができる．本論文 では，写真や文字などを含めて，QR コードに挿入する 画像をイラストと呼ぶ .

\section{2 定式化}

提案する方式では，QR コードへイラストを挿入する 問題を, $\left(4 \times N_{i}+1\right)$ 次元の設計変数を含む最適化問題 へ定式化する. $N_{i}$ は挿入するイラストの数を表し，イ ラスト毎に配置座標 $x_{i}, y_{i}$, 拡大縮小率 $s_{i}$, 配置角度 $\theta_{i}$ の 4 つの変数を用意する . また, $\mathrm{QR}$ コードの回転角 度を变数 $\theta_{Q R}$ として用意する. $\theta_{Q R}$ は $0^{\circ}, 90^{\circ}, 180^{\circ}$ または $270^{\circ}$ のいずれかの值をとる変数であり, $x_{i}, y_{i}$, $\theta_{i}$ は $[-180,180]$ の整数值, $s_{i}$ は実数值とする . 図 3 に， 本問題における設計変数を示す. 遺伝的アルゴリズムを 用いる場合は，遺伝子コード (GTYPE) が図 3(a) に 示す設計変数列に, 表現型 (PTYPE) [11] が図 3(b)に 示すイラスト入り QR コードとなる .

${ }^{\dagger}$ http://d-qr.net/index.htm 


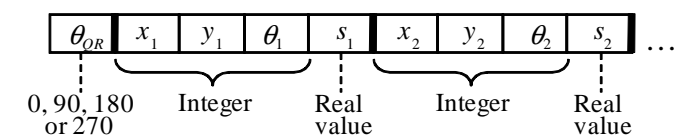

ex. \begin{tabular}{|l|l|l|l|l|l|l|l|l|}
0 & 100 & 85 & 20 & 0.7 & 32 & 114 & 0 & 0.48 \\
\hline
\end{tabular}

(a) 設計変数

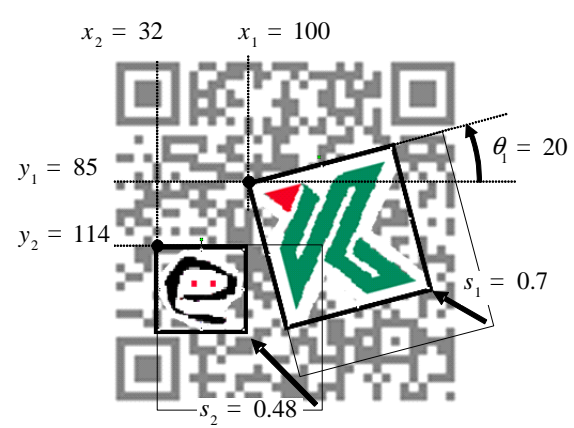

(b) 設計変数に基づくイラスト配置

図 3: 最適化問題への定式化

\begin{tabular}{|cl|}
\hline 1: & begin \\
2: & make individuals $C_{i}$ by random \\
3: & repeat \\
4: & generate decorated QR code images (PTYPE) \\
& from $C_{i}$ \\
5: & apply QR code decoders to the decorated QR \\
& code images and calculate $P\left(C_{i}\right)$ \\
6: & calculate $Q\left(C_{i}\right)$ and fitness $F\left(C_{i}\right)$ \\
7: & select elites to preserve \\
8: & crossover by BLX- $\alpha$ \\
9: & mutation \\
10: & until the stop condition is satisfied \\
11: & end \\
&
\end{tabular}

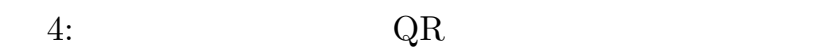
順（GA を用いた例）

\section{3 処理手順}

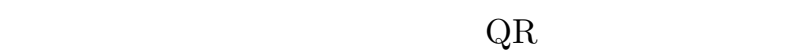
は，QR コードおよび合成するイラストを入力とする . 提案する方式は, 解候補, すなわちイラスト入り $\mathrm{QR}$ コード案の生成と, ソフトウェアデコーダを用いた解候 補の評価とを繰り返すことで, 埋め込まれたデータを損 ねないようにイラストを挿入することができる．解候補 の生成と評価は，一般の最適化アルゴリズムを用いる ことで行える . 本章で提案するイラスト入り静止画 $\mathrm{QR}$ コード生成方式では, 実数表現の遺伝的アルゴリズム
(Real-Coded Genetic Algorithm: RCGA) [8, 9, 10] 用いる.これは，RCGA を利用することで多数のイラ ストを挿入する高次元な問題であっても実用的な準最適 解の発見が期待できるためであり，また，RCGA は一 般的なアルゴリズムであり挙動が容易に把握できるた めである .

図 4 に，RCGA を用いた場合のイラスト入り静止画 $\mathrm{QR}$ コードの生成手順を示す . まず, $n$ 個の個体 $C_{i}$ を ランダムに生成する．次に， $C_{i}$ の GTYPE をもとに PTYPE の生成，すなわちイラスト入り QR コードの描 画を行い, ソフトウェアデコーダを用いてデコードを試 みる.イラストを挿入した QR コードの外観を評価し， デコード結果とあわせて,$C_{i}$ の適応度 $F\left(C_{i}\right)$ を算出す る.得られた適応度をもとに,エリート保存, 選択, 交 叉 , 突然変異などの遺伝的操作を行う. 適応度が 1.0 の 解を発見するか，あらかじめ定められた世代に達するま で，上記の解候補生成と評価を繰り返す。

\section{4 交叉: BLX- $\alpha$}

提案する方式で用いる RCGA では，BLX- $\alpha$ (Blend crossover）[10] を用いて交叉を行い，新しい解候補 を生成する.ランダムに選択された 2 個の親個体 を $a_{1}=\left(a_{1}^{(1)}, a_{1}^{(2)}, \ldots\right), a_{2}=\left(a_{2}^{(1)}, a_{2}^{(2)}, \ldots\right)$ とす る. 各設計変数 $d$ 毎に, 子個体 $c_{1}=\left(c_{1}^{(1)}, c_{1}^{(2)}, \ldots\right)$, $c_{2}=\left(c_{2}^{(1)}, c_{2}^{(2)}, \ldots\right)$ の設計变数値 $c_{1}^{(d)}, c_{2}^{(d)}$ を, $\left[\min \left\{a_{1}^{(d)}, a_{2}^{(d)}\right\}-\alpha I, \max \left\{a_{1}^{(d)}, a_{2}^{(d)}\right\}+\alpha I\right]$ の範囲か ら一樣分布に従う乱数を用いて決定する.ここで， $I=$ $\left|a_{1}^{(d)}-a_{2}^{(d)}\right|$ は設計変数 $d$ における 2 個の親個体間の距 離， $\alpha$ はどの程度の親個体間外の区間を，子個体の生成 範囲とするかを決定するパラメータである．

\section{5 解候補の評価}

提案する方式は, 解候補 $C$ の評価值 $F(C)$ を, デコー ド可能性 $P(C)$ およびイラスト配置の品質 $Q(C)$ の 2 つ の観点から算出する .

$$
F(C)=P(C) \times Q(C)
$$

樣々な種類の携帯電話でデコードを行えるよう, 複数 のソフトウェアデコーダを用いて解候補 $C$ のデコード 可能性 $P(C)$ を評価する . 图 5 に示すように , 複数のデ コーダで $C$ のデコードを試み，デコードの成功度合お よび以下の式 $(2)$ に従って $P(C)$ を算出する.

$$
P(C)=\frac{\sum_{k} p_{k}(C) \times w_{k}^{(p)}}{\sum_{k} w_{k}^{(p)}}
$$

$p_{k}(C)$ はデコーダ $k$ のデコード結果により算出され , デ コード $k$ が $C$ を正しくデコードできた場合は $p_{k}(C)=$ 1 , デコードに失敗した場合は, エラーの度合に応じて 
$p_{k}(C)$ の值を 1 から減点する . デコードに失敗した場合 に , デコーダ $k$ がエラーの度合を出力することができ ない場合は $p_{k}(C)=0$ とする.$w_{k}^{(p)}$ は各デコーダの重 みを表すパラメータである .

本論文では, ソフトウェアデコーダとして , 有限会社 サイテックが販売する QR コードデコードライブラリ ， およびオープンソース QR コードライブラリミを用いる . サイテックのデコーダを利用する場合は, デコード失敗 時の誤りの割合に関する情報を用いることはできない． オープンソースのデコーダを利用する場合は, デコード 結果と埋め込んだ情報との間で一致する割合をビット単 位で求め, デコード失敗時の誤りの割合とする .

イラスト配置の品質 $Q(C)$ は, 以下の式 (3) を用いて 計算する .

$$
Q(C)=\prod_{l} q_{l}(C)^{w_{l}^{(q)}}
$$

本章で提案する方式はイラスト入り静止画 $\mathrm{QR}$ コード を作成するものであり， $Q(C)$ を計算するために, 4 項 目を評価する . 各項目の評価值 $q_{l}(C)$ は 0 から 1 の間で 正規化されており, 重み $w_{l}^{(q)}$ によって重要度か調整さ れる .

$q_{1}(C)$ は, $C$ に含まれるイラスト同士の重なり具合を もとに計算される評価值であり，イラストが重なる場合 は $q_{1}(C)$ の值が低下する .

$$
q_{1}(C)=\max \left(1-\sum_{i=1}^{N_{I}} \frac{S_{i}^{O}}{S_{i}}, 0\right)
$$

ここで, $N_{I}$ は $C$ に埋め込まれるイラストの総数， $S_{i}$ は

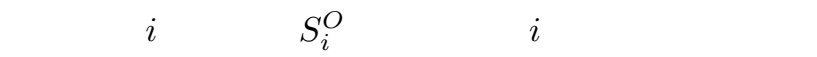
ストによって覆われる部分の面積を示す .

$q_{2}(C)$ は, $\mathrm{QR} コ ー ト ゙$ 外へのイラストのはみ出し具合 をもとに計算される評価值であり，イラストが QR コー ド外へはみ出すほど $q_{2}(C)$ の值が低下する .

$$
q_{2}(C)=\max \left(1-\sum_{i=1}^{N_{I}} \frac{S_{i}^{B}}{S_{i}}, 0\right)
$$

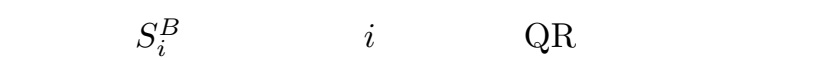
はみ出している部分の面積を示す .

$q_{3}(C)$ は，イラストの総面積に基づく評価値であり， $\mathrm{QR}$ コードに対してイラストの占める割合が大きすぎ る，または小さすぎる場合は $q_{3}(C)$ の值が低下する .

$$
q_{3}(C)=\min \left(\frac{\sum_{i=1}^{N_{I}} S_{i}}{R \times S_{Q R}}, 1\right)
$$

\footnotetext{
${ }^{\ddagger} \mathrm{QR}$ コードデコードライブラリ (有限会社 サイテック) http://www.psytec.co.jp/product/03/

§オープンソースの QR コードライブラリ開発プロジェクト http://qrcode.sourceforge.jp/
}

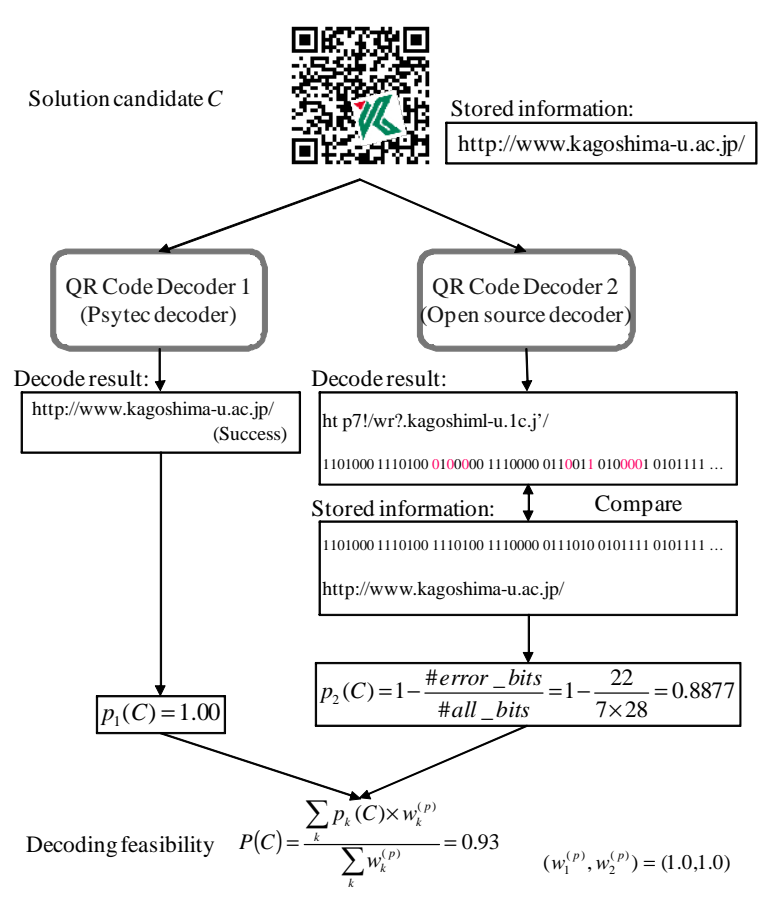

図 5: 複数のデコーダを用いたデコード可能性の評価

ここで， $S_{Q R}$ は $\mathrm{QR}$ コードの面積を示し， $R$ はイラス トの総面積と $\mathrm{QR}$ コードの比の目安となるパラメータ である

$q_{4}(C)$ はイラストの拡大縮小率のばらつきに基づく評 価値であり，イラスト間の拡大縮小率に大きな差がある 場合は $q_{4}(C)$ の值が低下する .

$$
q_{4}(C)=\frac{\min _{i=1, \ldots, N_{I}} s_{i}}{\max _{i=1, \ldots, N_{I}} s_{i}}
$$

ここで, $\max s_{i}$ および $\min s_{i}$ は弚れ艺れ，拡大縮小率 の最大および最小の值を示す .

\section{4 アニメーション QR コード生成方式への} 拡張

\section{1 方針}

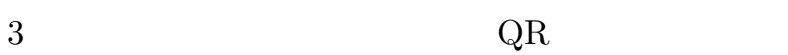
拡張することで, イラスト入り動画 QR コードの生成 が可能である.静止画 QR コードを生成する場合と異 なる点は以下の 3 点である .

1）挿入するイラストの位置を事前に指定する．各フ レームにおけるイラストの位置は事前に指定され るものとする . 指定された位置に単純にイラストを 挿入すると QR コードに埋め込まれたデータを損 ねてしまう場合は, デコードが可能であり，かつ， 
指定された位置になるべく近づくようにイラスト を配置する

2）複数枚のイラスト入り静止画 QR コードを生成し, 連続して再生することで動画 QR コードを生成す

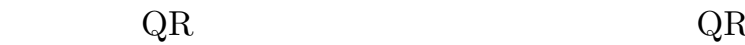
コードは，1 フレームずつ個別に生成する．これに より，問題サイズの爆発的な増大を抑えることが できる .

3) 最適化アルゴリズムとして山登り法( HillClimbing: HC) を利用する. 各フレームにおけ るイラストの希望配置位置は事前に指定されてお り，最適化アルゴリズムは希望配置位置を中心と して局所的に探索を行えばよい．このため，比較 的単純な HC であっても十分な品質の準最適解を 発見することができる．

\section{2 処理手順}

イラスト入り動画 QR コード生成方式の処理手順を 图 6 に示す.与えられたイラストおよび关れらの希望配 置位置をもとに，フレームごとにイラスト入り静止画 $\mathrm{QR}$ コードを作成する．なお，QR コードの方向 $\theta_{Q R}$ は あらかじめ定められた值に固定する .

各フレームは，3 章で述べた方法により作成するが， RCGA ではなく HC を用いる点が異なる. $\mathrm{HC}$ は単点 探索アルゴリズムであり，単一の解候補 $C$ のみを保持 する . 各探索ステップにおいて, 現在の解候補 $C$ の近 傍の解候補 $C_{i}^{\prime}$ を生成して最も評価値 $F\left(C_{i}^{\prime}\right)$ が高い解候 補 $C_{h}^{\prime}$ を選出し, $F\left(C_{h}^{\prime}\right) \geq F(C)$ の場合は $C$ を $C_{h}^{\prime}$ で置 き換える。

本論文で提案する方式では，以下の条件のいずれか を満たした場合に各フレームの探索を終了するものと した。

1. あらかじめ定められた探索ステップを繰り返した 場合，探索を終了する.このとき，得られた最良解 $C_{b}$ の評価值 $F\left(C_{b}\right)$ が 0.8 以下であった場合は，デ コード可能性を維持しつつ指定された位置にイラ ストを挿入することは困難と判断し，デコード可 能性を考慮せずに，指定された位置にイラストを 挿入する .5 章の実行例では, 100 ステップを上限 として探索を打ち切るものとした .

2. 一定以上の探索ステップの間 , 評価値の改善がみ られない場合は探索を終了する.5 章の実行例で は，20 ステップを閾值として探索を打ち切るもの とした。

3. 一定以上の評価値を得た場合，十分な品質の最適 解を発見できたとして探索を終了するものとした .

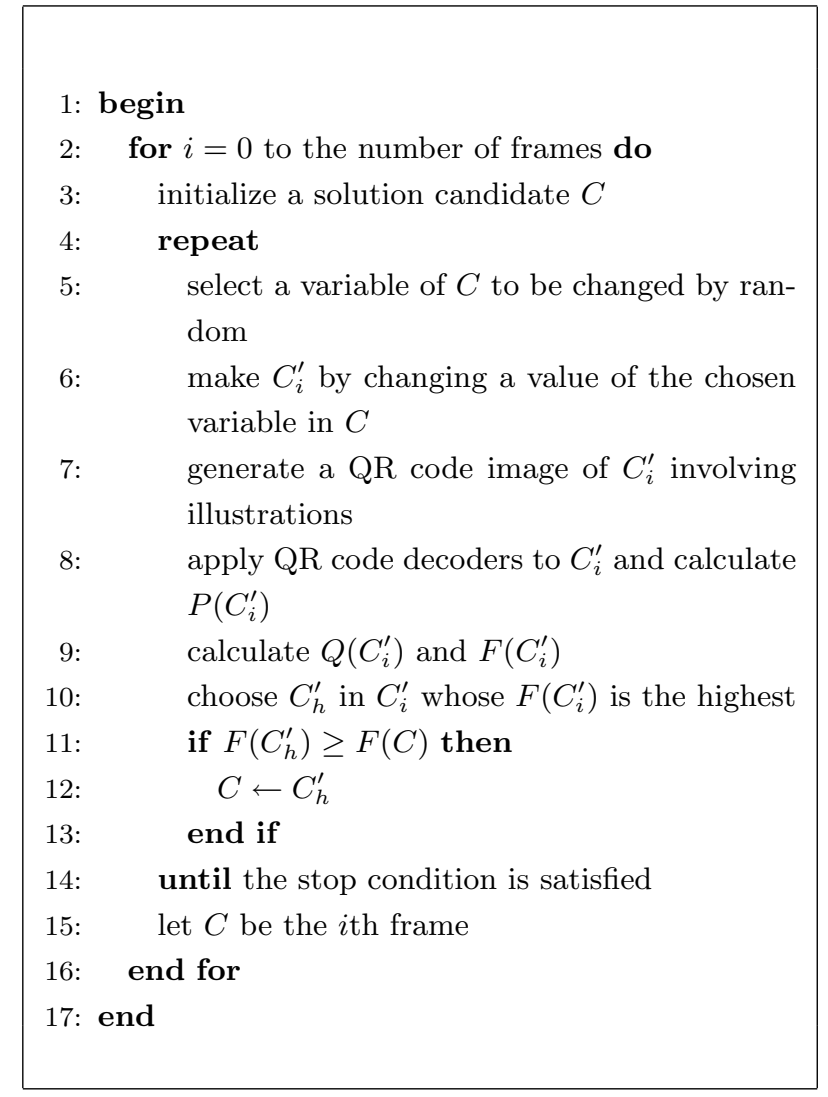

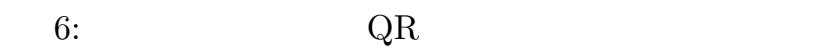
(HC を用いた例)

5 章の実行例では, 評価值 0.95 を閾值として探索 を打ち切るものとした .

\section{3 解候補の評価}

イラスト入り動画 $\mathrm{QR}$ コード生成において, 各フレー ムの評価は式(1) を用いて行うことができるものの,ユー ザが指定した位置に近づくようにイラストを配置する ことを優先するため, 式 (4) から式 (7) の 4 つの関数の かわりに，以下の式 (8)，(9) および (10)を用いる .

$$
\begin{gathered}
q_{5}(C)=\max \left(1-\sum_{i} \frac{\left(\left(x_{i}-\bar{x}_{i}\right)^{2}+\left(y_{i}-\bar{y}_{i}\right)^{2}\right)^{\frac{1}{2}}}{\left(S_{Q R}\right)^{\frac{1}{2}}}, 0\right) \\
q_{6}(C)=\max \left(1-\sum_{i}\left|s_{i}-\bar{s}_{i}\right|, 0\right) \\
q_{7}(C)=\max \left(1-\sum_{i} \frac{\delta\left(\theta_{i}, \bar{\theta}_{i}\right)}{180}, 0\right)
\end{gathered}
$$

$q_{5}(C)$ は指定されたイラスト $i$ の位置 $\bar{x}_{i}, \bar{y}_{i}$ と解候 補 $C$ においてイラスト $i$ か配置された位置 $x_{i}, y_{i}$ との 差異を， $q_{6}(C)$ および $q_{7}(C)$ は指定されたイラスト $i の$ 倍率 $\bar{s}_{i}$, 角度 $\bar{\theta}_{i}$ と $C$ における拡大縮小率 $s_{i}$, 角度 $\theta_{i}$ 


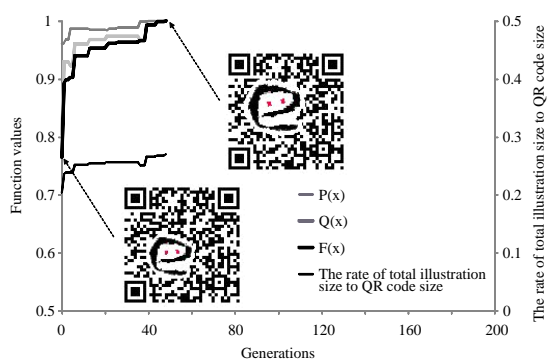

(a) イラスト 1 個

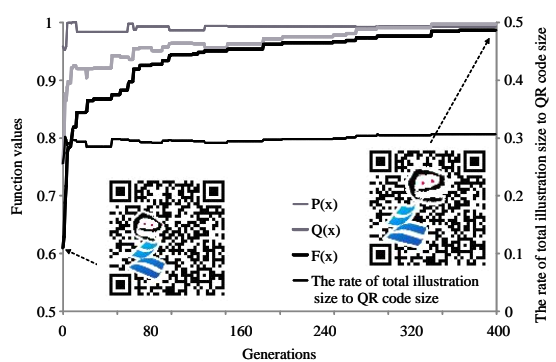

(b) イラスト 2 個

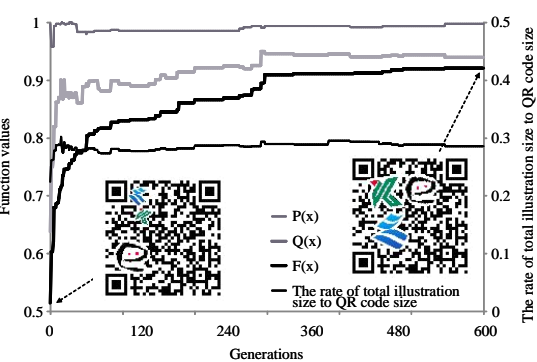

(c) イラスト 3 個

図 7: 静止画 $\mathrm{QR}$ コード生成時の解候補評価値の推移

表 1: 静止画 QR コードを生成する際のパラメータ設定

\begin{tabular}{lr}
\hline Parameter & Value \\
\hline Number of individuals & 10 \\
Number of elites & 2 \\
Crossover & BLX- $\alpha$ \\
$\alpha$ & 0.2 \\
$R$ & 0.1 \\
Crossover rate & 0.8 \\
Mutation rate & 0.03 \\
Generations & $N_{I} \times 200$ \\
\hline$\left(w_{1}^{(p)}, w_{2}^{(p)}\right)$ & $(0.8,0.2)$ \\
$\left(w_{1}^{(q)}, w_{2}^{(q)}, w_{3}^{(q)}, w_{4}^{(q)}\right)$ & $(0.5,0.5,1.0,0.5)$ \\
\hline
\end{tabular}

との差異を乥れ光れ表す関数である. $\delta\left(\theta_{i}, \bar{\theta}_{i}\right)$ は,$\theta_{i}$ と $\bar{\theta}_{i}$ の差のうち，小さい方の角度差である .

$$
\delta\left(\theta_{i}, \bar{\theta}_{i}\right)=\min \left(\left|\theta_{i}-\bar{\theta}_{i}\right|,\left|\bar{\theta}_{i}-\theta_{i}\right|\right)
$$

なお， $q_{5}(C), q_{6}(C)$ および $q_{7}(C)$ は，イラスト入り 静止画 QR コードを生成する際に, ユーザが (全てま たは一部の) イラストの位置を指定した場合にも利用す ることができる .

\section{5 実行例}

\section{1 イラスト 入り静止画 QR コード}

3 章で提案した方式を用いて，イラスト入り静止画 QR コードの生成を試みた .なお，本論文の実験で用い た QR コードは，すべて誤り訂正レベルを $\mathrm{H}$ とした .

解候補の評価を行う関数（式 (1) および式 (2)) にお ける各デコーダの重みは, サイテック製のデコーダの重 み $w_{1}^{(p)}$ を 0.8 , オープンソースデコーダの重み $w_{2}^{(p)}$ を 0.2 とした .これは, オープンソースデコーダは開発段 階であり, サイテック社のデコーダの方が信頼性が高い ためである .
また，式 (3)における $w_{1}^{(q)}, w_{2}^{(q)}, w_{3}^{(q)}$ および $w_{4}^{(q)}$ を，光れ光れ $0.5 ， 0.5 ， 1.0 ， 0.5$ とし，式(6)における Rの值を 0.1 とした . パラメータ設定の一覧を表 1 に示 す. 表 1 における $N_{I}$ は, 挿入するイラストの個数を表 す. 提案する方式では, 単一の準最適解を発見できれば 十分であるため, 個体数が 10 の，一般の GA と比較す ると小規模な集団を用いる，弚の他の值は，予備実験な どにより経験的に決定した .

1 個から 3 個のイラストを挿入する場合の, 集団内 の最良の解候補 $C_{h}$ の $F\left(C_{h}\right), P\left(C_{h}\right), Q\left(C_{h}\right)$ の推移， および，QR コードの面積に対するイラスト面積の割合 の推移を図 7 に示す. 本実験では , バージョン 5 の QR コードを用いた . 図 7 から, 埋め込むイラスト数か増 加すると， $F\left(C_{h}\right)$ が高い值の解を生成するまでにより 多くの世代数を要し,より長い処理時間が必要であるこ とがわかる.また，探索序盤から中盤にかけて，デコー ド可能性 $P\left(C_{h}\right)$ が十分に高い解候補を生成できており， 探索終盤にかけて品質 $Q\left(C_{h}\right)$ を徐々に高めていくこと がわかる.

挿入すイラストの種類や個数を変化させた場合の， イラスト入り QR コードの生成例を図 8 に示す. 図 8(a)

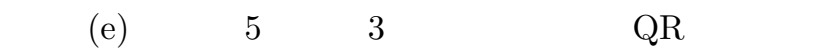
挿入した例である . 図 $8(\mathrm{f})$ は 5 個のイラストを, $(\mathrm{g})$ は 10 個のイラストを，(h) は 1 個のイラストを挿入した例 である.図 8(c)，(e)，(f) はバージョン 4, (d) はバー ジョン $6,(\mathrm{a}),(\mathrm{b}),(\mathrm{h})$ はバージョン $8,(\mathrm{~g})$ はバージョ ン9の QR コードを用いた .

(a) は携帯電話のメールアドレスが，(b) は航空会社 の電話番号『が，光れ光れ埋め込まれていることを示し ており，QR コードに埋め込まれている情報の種類を直 観的に表現している.また，図 8(f) のような音符のイ ラストを挿入することで, 携帯電話の着信音を取得する Web ページなど，音に関する情報を含むことを历めか すことができる

本方式でイラスト入り QR コードを生成する際に，ソ

\footnotetext{
『本論文では例示しないが，会社のロゴを埋め込むことで，埋め込 まれている情報をより直観的に表すことができる．
} 


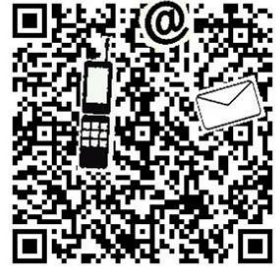

(a) Example 1

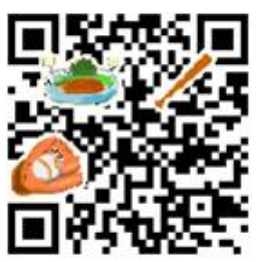

(c) Example 3

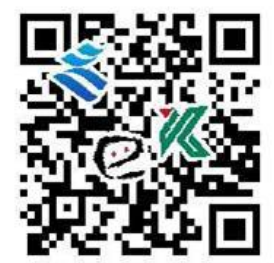

(e) Example 5

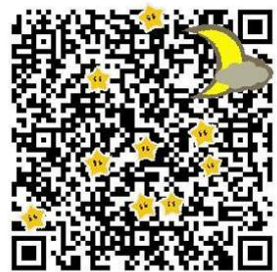

(g) Example 7

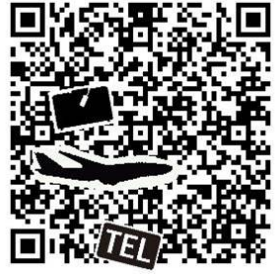

(b) Example 2 .

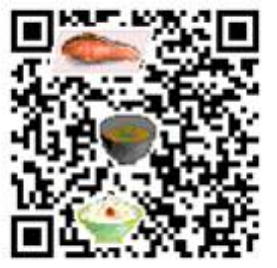

(d) Example 4.

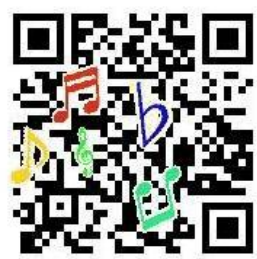

(f) Example 6

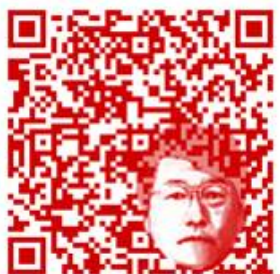

(h) Example 8.
図 8: 生成した静止画 $\mathrm{QR}$ コードの例

フトウェアデコーダでは正しくデコードが行えたイラ スト入り $\mathrm{QR}$ コードであっても，携帯電話で正しくデ コードできないことがある . 携帯電話による QR コー ドからの情報の抽出は，QR コードを含む画像の撮影， 撮影した画像からの QR コード領域の抽出，抽出した $\mathrm{QR}$ コードのデコードの 3 段階で行われる . すなわち， ソフトウェアデコーダでデコード可能なイラスト入り $\mathrm{QR}$ コードであっても，撮影した画像からの QR コード 領域の抽出に失敗すると，携帯電話ではデコードを行う ことができない，携帯電話上での $\mathrm{QR}$ コード領域の抽 出方法は公開されていないため, 提案する方式で考慮す ることは難しい .

提案する方式を利用したイラスト入り $\mathrm{QR}$ コードの 生成に要する時間は，図 8(e) の 3 個のイラストを埋め 込んだ $\mathrm{QR}$ コードを作成する場合で, 平均 5,623 秒 , (g) の 10 個のイラストを埋め込んだ $\mathrm{QR}$ コードを生成する
表 2: 動画 $\mathrm{QR}$ コードを生成する際のパラメータ設定

\begin{tabular}{lr}
\hline Parameter & Value \\
\hline Number of neighbors & 20 \\
at each iteration & \\
Iteration limit for each frame & 100 \\
$\alpha$ & 0.2 \\
$R$ & 0.1 \\
\hline$\left(w_{1}^{(p)}, w_{2}^{(p)}\right)$ & $(0.8,0.2)$ \\
$\left(w_{1}^{(q)}, w_{2}^{(q)}, w_{3}^{(q)}, w_{4}^{(q)}\right.$, & $(0.0,0.0,0.0,0.0$ \\
$\left.w_{5}^{(q)}, w_{6}^{(q)}, w_{7}^{(q)}\right)$ & $0.5,1.0,1.0)$ \\
\hline
\end{tabular}

場合で平均 7,541 秒であった川 .

5.2 イラスト入りアニメーション QR コード

4 章で提案した方式を用いて，イラスト入り動画 $\mathrm{QR}$ コードの生成を試みた . パラメータ設定の一覧を 表 2 に示す.式 (2) における重みは，5.1 節と同樣， $\left(w_{1}^{(p)}, w_{2}^{(p)}\right)=(0.8,0.2)$ とした . また, 式 $(3)$ にお ける重みは, $\left(w_{1}^{(q)}, w_{2}^{(q)}, w_{3}^{(q)}, w_{4}^{(q)}, w_{5}^{(q)}, w_{6}^{(q)}, w_{7}^{(q)}\right)=$ $(0.0,0.0,0.0,0.0,0.5,1.0,1.0)$ とした .これは, 動画 $\mathrm{QR}$ コードを生成する場合は，指定された位置の近辺に各 イラストの配置を試みるため，イラスト同士の重複な どを考慮する必要がないためである . 各フレームを $\mathrm{HC}$ によって生成する際の探索ステップの上限は 100 ステッ プとした

生成したイラスト入り動画 QR コードの例を図 9，10 および 11 に示す . 図 9 は，携帯電話の着信音を取得で きるURL を埋め込むことを想定した動画 QR コードで ある.図 10 は, 電車内や駅構内, バス停などに設置さ れた小型ディスプレイに表示し, 近隣の飲食店の地図 か記載された URL を埋め込むことを想定した動画 QR コードである.図 11 は，食料品販売店の店頭に設置し た小型ディスプレイに表示し，販売している食材を用 いた料理の調理方法が記載された URL を埋め込むこと を想定した動画 QR コードである. 図 $9 ， 10$ および 11 の実行例は光れ光れ，4，4，5個のイラストを用いてお

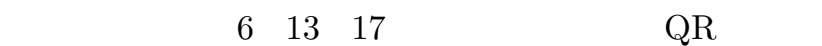
から構成されている.図 9,10 および 11 の QR コード

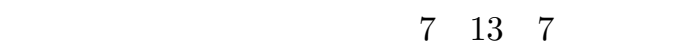

図 9,10および 11 から，テレビやディスプレイ等の 動画像を表示できる媒体の利点を活かした , 視覚的誘引 性の強い QR コードを生成できることがわかる．また 図 11(b) の第 4 フレームは, 携帯電話によってはデコー ドが困難なことがある . しかし , 次の第 5 フレーム以降

$\| \mathrm{PC} / \mathrm{AT}$ 互換機 1 台 (CPU: Pentium $42.53 \mathrm{GHz}$, Mem.: 1GByte, OS: Microsoft Windows XP) を用いた.GA は確率的 なアルゴリズムであるため, 5 回試行を行った場合の平均処理時間を 示している . 


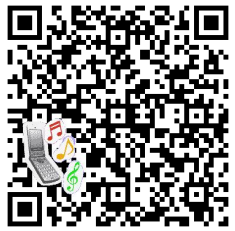

a) 1st Frame.

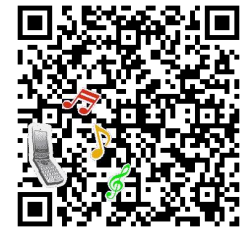

b) 2nd Frame.

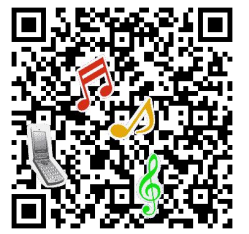

c) 3rd Frame.

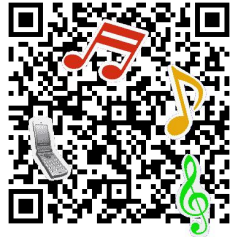

d) 4th Frame.

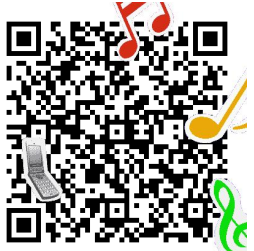

e) 5th Frame.

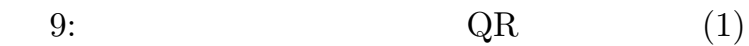

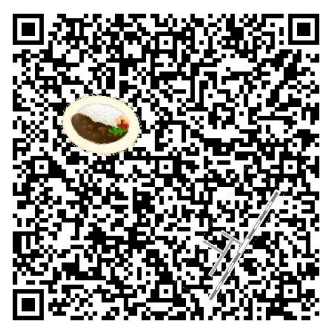

(a) 2nd frame.

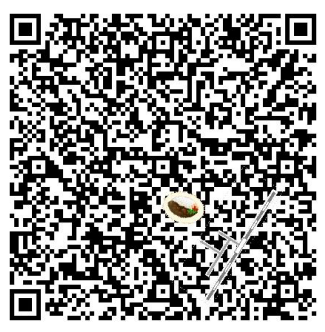

(b) 5 th frame.

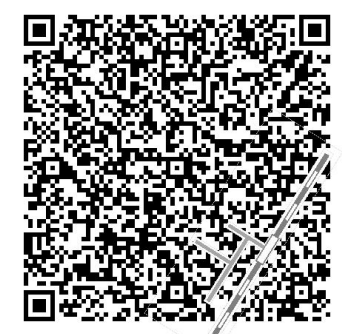

(c) 9th frame

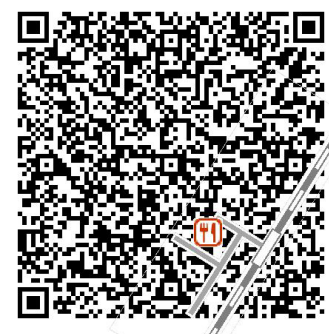

(d) 11th frame

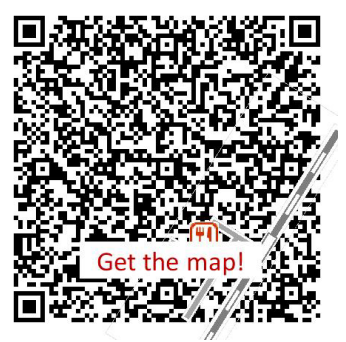

(e) 12 th frame.

図 10: 生成したアニメーション $\mathrm{QR}$ コードの例 $(2)$

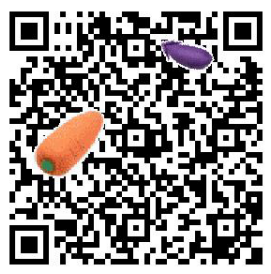

(a) 3rd frame

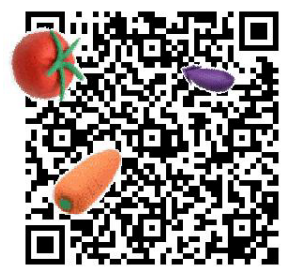

(b) 4th frame.

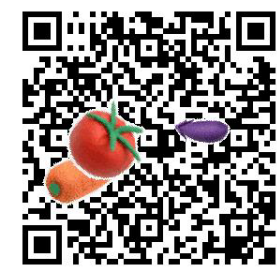

(c) 6th frame.

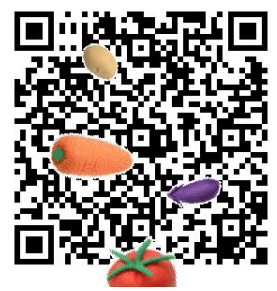

(d) 9 th frame.

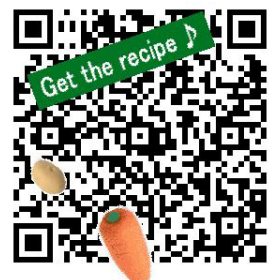

(e) 15th frame.

図 11: 生成したアニメーション $\mathrm{QR}$ コードの例 (3)

に表示が切り替わつた際に問題なくデコードを行える ため，動画 QR コード全体としては単一フレームでデ コードが行えなくとも実用性への影響は少ない .

図 9,10および11のイラスト入り動画 QR コードを 生成するために要した時間は光れ光れ，約 310 秒，約 441 秒，約 2,032 秒であった。

\section{6 おわりに}

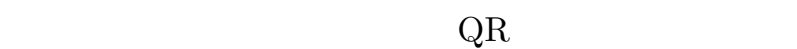
メーション $\mathrm{QR}$ コードを自動生成する方式を提案した． 本方式は，イラスト挿入位置決定を最適化問題として定 式化し，汎用の解探索アルゴリズムを用いた求解によ り，埋め込まれたデータが損なわれないように QR コー ドにイラストを挿入することができる．また，複数の
$\mathrm{QR}$ コードデコーダを用いることで, 樣々な携帯電話で 読み取ることができるイラスト入り QR コードを作成 できる.提案する方式を用いて実際にイラスト入り静止

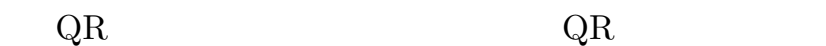
し，樣々な携帯電話て読み取りが可能であることを確認 した .

今後 , パラメータの自動調整の実現 , イラスト初期位 置指定を容易に行えるインタフェースの実装, デザイナ と協調した対話的な QR コードの装飾を可能とするた めデザイン発想支援 $[12,13,14]$ の援用などを行う予定 である . 


\section{参考文献}

[1] Rohs, M.: Real-World Interaction with Camera Phones, Proceedings of 2nd International Symposium on Ubiquitous Computing Systems 2004, pp. 74-89 (2004).

[2] Reed, I. S. and Solomon, G.: Polynomial Codes Over Certain Finite Fields, SIAM Journal of Applied Mathematics, Vol. 8, pp. 300-304 (1990).

[3] 佐藤潔之 : 任意の指定した画像を模樣として持つ、 二次元コード生成システム, 公開特許広報 $(\mathrm{A})$ 特 開 2007-34998 (2007).

[4] Rich, E. and Knight, K.: Artificial Intelligence, Mcgraw-Hill College (1990).

[5] Gent, I. P. and Walsh, T.: Towards an understanding of hillclimbing procedures for SAT, Proceedings of Eleventh National Conference on Artificial Intelligence(AAAI93), pp. 28-33 (1993).

[6] Kirkpatrick, S., Gelatt, C. D. and Vecchi, M. P.: Optimization by Simulated Annealing, Science, Number 4598, 13 May 1983, Vol. 220, 4598, pp. 671-680 (1983).

[7] Goldberg, D. E.: Genetic Algorithms in Search, Optimization, and Machine Learning, Addison Wesley, Reading (1989).

[8] Wright, A. H.: Genetic Algorithms for Real Parameter Optimization, Foundations of genetic algorithms (Rawlins, G. J., ed.), Morgan Kaufmann, San Mateo, CA, pp. 205-218 (1991).

[9] Eshelman, L. J. and Schaffer, J. D.: Real-Coded Genetic Algorithms and Interval-Schemata, Foundations of Genetic Algorithms, Vol. 2, pp. 187-202 (1993).

[10] Eshelman, L. J., Mathis, K. E. and Schaffer, J. D.: Crossover Operator Biases: Exploiting the Population Distribution (1997).

[11] 伊庭斉志：進化論的計算手法，才ーム社出版局 (2004).

[12] 鲗見達夫 : 品種改良でCG 画像を作る模擬育種シス テム , Computer Today, No. 64, pp. 76-82 (1994).

[13] Takagi, H.: Interactive Evolutionary Computation - Fusion of the Capabilities of EC Optimization and Human Evaluation, Proceedings of the IEEE, Vol. 89, pp. 1275-1296 (2001).
[14] Serag, A. , 小野智司，中山 茂: 対話型進化計算法 を用いた建造物デザイン発想支援の基礎検討，情 報処理学会論文誌, Vol. 47, No. 6, pp. 2764-2768 (2006). 